\title{
"Rainforestation Farming" - an Appropriate and Applied Ecological Approach for Landscape Rehabilitation and Impact Mitigation of Climate Change in the Humid Tropics
}

\author{
Friedhelm Göltenboth ${ }^{1}$ \\ ${ }^{1}$ University of Hohenheim, Institute of Plant Production and Agroecology in the \\ Tropics and Subtropics Garbenstr. 13, D-70593 Stuttgart, Germany
}

\begin{abstract}
While the last century was mainly focusing on conservation measures in landscape ecology, the present century has certainly to deal with restoration, rehabilitation and reclamation of entire landscapes.

Aspects and forms of degradation are discussed in this paper showing the complexity of the task ahead for researchers and applied agriculturists.

The tropical forested areas are of special concern under the aspect of their enormous variety of biotopes and biocoenosis and their protective functions and ecological services to man in a given landscape.

The specific responsibility of agro-forestry systems is described and the innovative "Rainforestation Farming" technology for rehabilitation of degraded landscapes in a "near-to-nature" farming system is described.

The gradual transformation of monocultures into highly diverse tree farming systems is discussed and also some aspects of global dimension, like the reduction of carbon dioxide and aspects of carbon sequestration.
\end{abstract}

Keywords: Rainforestation Farming, applied tropical ecology, landscape rehabilitation, humid tropics

Correspondence: Friedhelm Göltenboth Address: University of Hohenheim, Institute of Plant Production and Agroecology in the Tropics and Subtropics Garbenstr. 13, D-70593 Stuttgart, Germany. E-mail: friedgoelten@gmx.de Tel: 0049-747321176

DOI: $10.32945 /$ atr3325.2011 


\section{INTRODUCTION}

It is well documented, how rapid landscape depletion swept through the tropics under the flag of development, since the 60s of the last century.

On all continents with tropical forests, vast primary forest areas were cleared, and land degradation started. The International Tropical Timber Organization (ITTO) distinguishes between three types of forest degradation:

- degraded primary forest resulting from excessive and damaging timber exploitation

- secondary forest spontaneously re-growing on land that had been largely cleared

- degraded forest land which is so degraded that forest re-growth has not occurred and which is now mostly occupied by grasses and shrubs.

Land degradation is of great concern due to the fact that more than 900 Million people do not have enough food on a daily base in 2010. By the year 2020, land degradation may pose a serious threat to food production and rural livelihood particularly in poor and densely populated areas leading to widespread unrest and political uncertainties.

Some degraded ecosystems are able to recover naturally in a succession that is often locally well adapted (Fig. 1), but many do not.

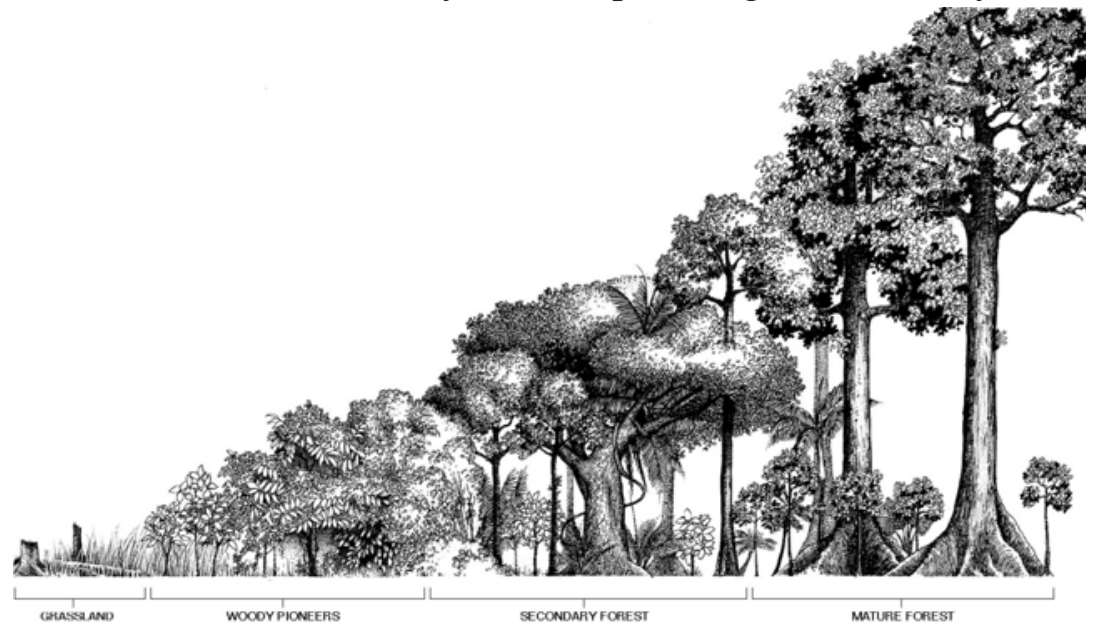

Figure 1. Succession of plant formation after major disturbance (Goeltenboth $e t$ al., 2006) 
Examples of successions are common but several preconditions must be met:

- The disturbing agents must be removed. If for example fire, timber harvesting or grazing continues a recovery is not possible

- Locally adapted animals and plants must still exist in the region or site as a source of new colonizers. The more distant these source populations are and the greater the degree of biological impoverishment in the intervening landscape, the slower is the recolonisation process. The more so-called "stepping stones" in the form of patches of natural forest are still in the region the faster the process will be.

- The soils in the area must also remain in a reasonable condition. New faunal and floral communities, possibly exotic species able to tolerate the changed environment, may take over if severe erosion has taken place or if soil fertility has been depleted.

- If the original community is to be re-established weed species or animal pests must be excluded.

A detailed typology of degraded tropical forested land was provided by Chokkalingam et al. (2001) (Fig. 2).

\section{Management of Degraded Lands}

Degradation can be overcome with a variety of approaches (Lamb and Gilmore, 2003) (Fig. 3):

- Restoration usually describes the methods used for those situations where the intent is to recreate an ecosystem as close as possible to that which originally existed at the site. This process aims to regain ecological integrity and enhance human well-being in deforested or degraded forest landscapes.

- Rehabilitation is used where the original productivity or structure is regained as well as some, but not all, of the original biodiversity. For ecological or economic reasons the new forest may include species not originally present. Protective functions and most ecological services may be re-established. 


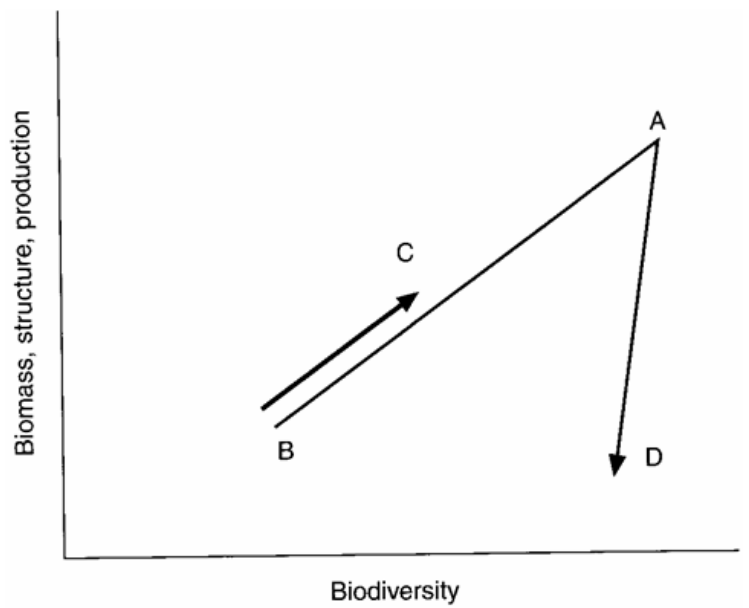

Figure 2. Forms of forest degradation (after Chokkalingam et al. 2001). The position A represents an undisturbed forested area. A certain level of biodiversity, biomass, structure and production are characteristic features of these forests. The position B is reached after extensive clearing. A very large proportion of the biodiversity as well as biomass, structure and productivity are lost. The position $\mathrm{C}$ marks so-called secondary re-growth forest. The $\mathrm{D}$ position indicates that even after some form of logging the degradation of the primary forest is still leaving a significant amount of biodiversity on the over-logged site.

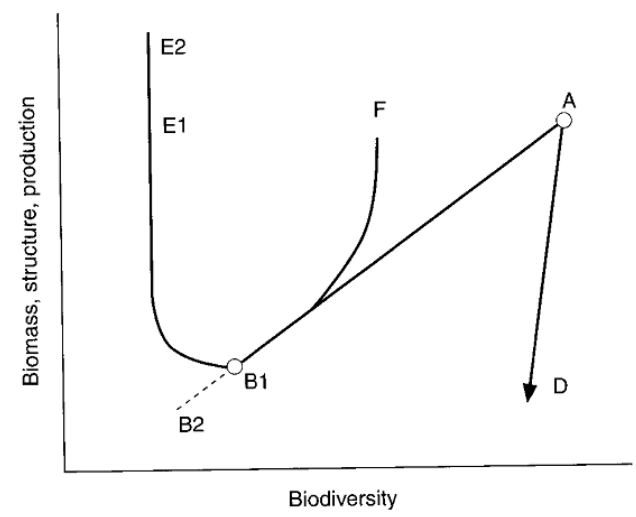

Figure 3. Diagrammatic graph showing the relations between ecological restoration, rehabilitation and reclamation (after Lamb\&Gilmour 2003). The degraded forest (B1) may degrade further over time to B2 by repeated wildfires). Through ecological restoration the forest may return to the Alevel. Reclamation measures takes it to E1 or E2 (e.g. site improved with fertilizer). Rehabilitation may bring it to F. The structure and biomass and some, but not all, of the original species richness have been recovered. 
- Reclamation is used for situations where productivity or structure is regained but biodiversity is not. Native species may not be used at all resulting in very few, if any, benefit to landscape biodiversity. Social and economical advantages or functional gains may exist (Tab.1).

Table 1. Prospects of reforestation using monoculture of exotic species (after Ingles and Jackson, 2001).

Potential Advantages

Potential Negative Consequences

- Supply of high-quality seeds

- Genetically manipulated plants are

- Nursery technology well understood released into the surroundings

- Reduction in range, quality and quantity of goods and services supplied to local people by new plantation

- Site and environmental requirements known

- Reduction in ecosystem services, water regulation, nutrient cycling and wildlife habitat

- Silviculture systems for managing plantations known

- Potentially high productivity

- Limited opportunities for collaborative management

- Susceptibility to climate and other environmental changes increased

- Tree timber properties known

- Loss of bio diversity and of opportunities to restore it

- Species tolerant of extremely poor soils or degraded sites can be chosen

- More frequent outbreaks of pest and diseases

- Problems with alien species becoming invasive

In this context the relationship between the quality of ecosystem restoration and the improvement that this brings to the well-being of humans living in or near the re-forested area, is of great importance, particularly under the aspect of acceptance by the people. Only if the measures are accepted could the efforts become sustainable.

This relatively broad term "human well-being" covers not only benefits such as market values like timber and non-timber products, or ecological services such as watershed protection, but also quality of life factors like health, education and culture (Fig. 4).

The methods applied for clearing were very often very destructive, leaving the landscapes in a deplorable state of exposure to the climatic impacts becoming increasingly problematic (Fig. 5).

In South Asia and East Asia for example the frequency of heavy storms and typhoons has dramatically increased leading to huge floods 


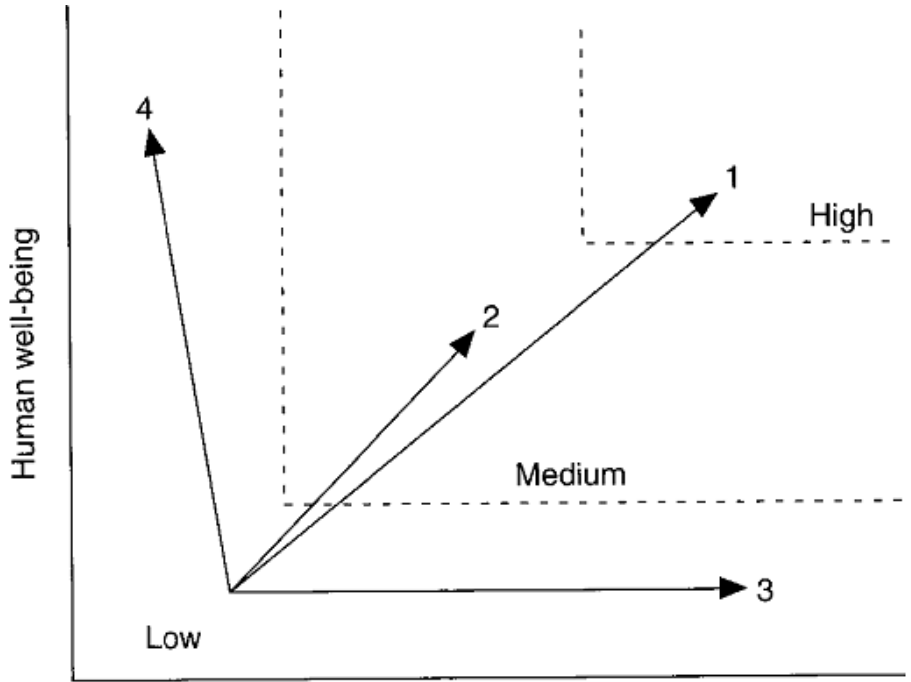

Ecosystem integrity

Figure 4. Connection between ecological integrity of restored and rehabilitated ecosystems and human well-being (after Lamb\& Gilmour 2003). The highest level of landscape restoration is at point 1 . Position 2 represents a less successful outcome. Less likely to be sustainable are the positions 3 and 4.

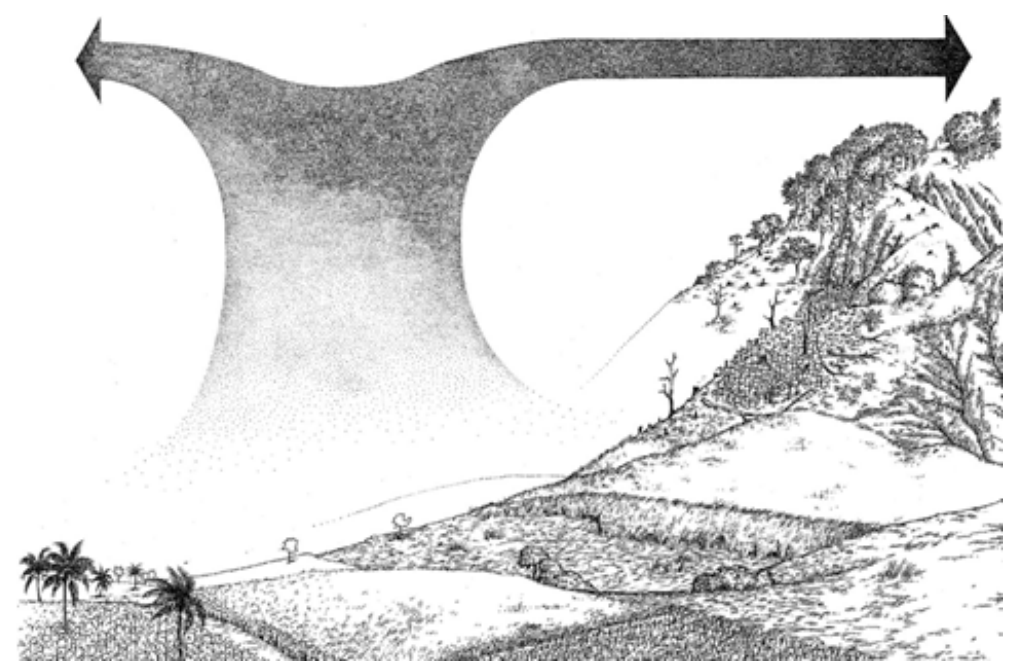

Figure 5. The changes of local climatic cycles and patterns due to inappropriate land-use systems without proper tree cover are far-reaching (Goeltenboth et al. 2006). 
in lowlands, like in Pakistan in 2010 and in Thailand in 2011, large scale erosion in the uplands, sedimentation of rivers, reservoirs, lakes and coral areas. Further, inferno-like forest fires like the month-long forest fires in the primary forest of Kalimantan and Sumatra in 1997-1998 and the fires in the subtropical forests in Australia and Israel in 2010 are becoming a regular feature.

It is well researched that forest cover, particularly in tropical regions, prone to heavy rains and storms, are mitigating the disastrous effects triggered in recent years by the ongoing process of climate change. Under this aspect the pressure on tropical forested areas is of great concern.

In particular the Tropical Evergreen Lowland Rainforest and the monsoon forests of the highlands disappear at a very alarming rate due the increasing demand for valuable tropical hardwood species and of palm-oil for agro-fuel.

The tropical and subtropical forest ecosystems with their enormous variety of biotopes and biocoenosis influence further the productivity and services provided by intact ecosystems. Varieties and changes in an ecosystem changes the ecosystem's ability to absorb pollution, to maintain soil fertility and micro-climates, cleanse water, provide options for new components of medicinal value, and other invaluable services.

Agriculture plays in this context a very important role. For generations low - input production systems as near- to- nature as possible produce a wide range of crops and livestock contributing to adequate watershed protection, maintenance and improvement of soil fertility and integrated pest-management strategies in a local context (Goeltenboth and Hutter, 2004).

An inevitable consequence of human development in a given landscape is the reduction of biodiversity. While traditionally cultivated agro-ecosystems support a relatively high level of biodiversity most modern agro-business-oriented systems degrade ecosystems into agricultural and biological "green deserts" ending very often as highly critical land. Due to greed and gross neglect of basic ecological principles overuse and misuse disrupt ecosystem functions, drive species into extinction and impose also costs and threats to mankind. It is no exaggeration that lack of foresight today in environmental matters comes with a high price tag for the future. 
The negative relationship among poverty, population, and environmental degradation can end only, according to research, with the help of more productive agriculture in the areas that have already been cultivated by the poor. Yet at the same time, changes need to be made where agriculture is more advanced, such as on former Green Revolution lands. More environmentally sound management of fertilizers, pesticides, and irrigation is needed to reduce the negative environmental impact of agricultural intensification. Increasing agricultural productivity in both the fragile and the more productive areas of the developing world is essential for meeting future global food needs (Wilson, 2001).

Environmental degradation sets in when the poor lose the capacity to support themselves from their natural resource base sustainable.

Efforts to preserve and rehabilitate ecosystems and simultaneously sustain human food production and income generation on the subsistence level and therefore to combine sustainable rural development, conservation of remaining primary ecosystems and biodiversity rehabilitation, led to the development of a "closed canopy and high diversity tree-based farming system, called "Rainforestation Farming". This system was developed during the 1990s on the island of Leyte in the Philippines (Milan and Margraf, 1994; Margraf and Milan, 1996; Goeltenboth, 1999; Schulte, 2002; Goeltenboth and Hutter, 2004). This system replaces the destructive and steadily shorter cycles of slash and burn practices (Fig. 6) usually starting when population pressure and a lack of adequate agricultural technologies are becoming the major forces that the poor make desperate choices. When a farm household in the humid tropical forest margin slashes and burns as the initial step in an agricultural cycle, it starts a clock ticking (Vosti, 2001).

Land cleared by burning forests loses stability and fertility within a few years; steep hillsides quickly become eroded without investments in soil conservation; marginal agricultural lands gradually become infertile when those who farm them can afford neither fertilizer nor longer fallow periods.

The need for diverse cropping systems instead of intensive monocultures of annual crops, a better integration of livestock and green manure into farming systems, and the generation of long-term sources of income are well researched. It is also obvious that the entire complex of land tenure rights is crucial to improve the situation particularly in fragile areas. 


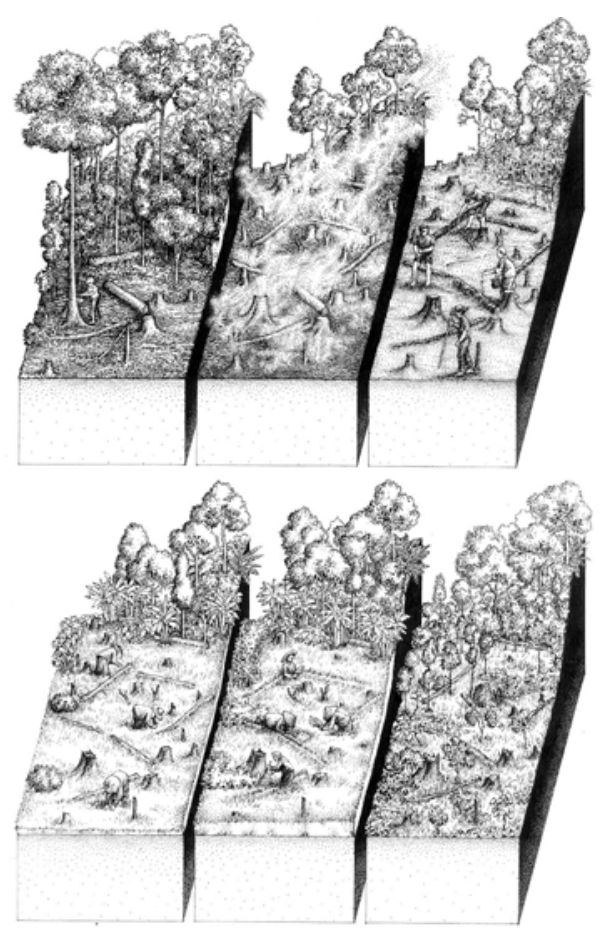

Figure 6. Succession of slash and burn practices in a humid tropical rainforest landscape (Goeltenboth et al., 2006).

In general a number of considerations have to be made like biophysical considerations, intervention at a site level e.g. biodiversity restoration considerations, ecological successions, productivity benefits and managing for goods, ecological services and biodiversity. However, rehabilitation that seeks to improve landscape biodiversity and functioning while generating productive output is especially difficult.

It is well documented that interventions at a site level with special focus on biodiversity restoration can follow different approaches depending on the specific status of the respective site (Parotta and Knowles, 2001). Restoration can be achieved simply by protecting the site from further disturbance and allowing natural colonisation and successional processes to restore ecosystem biodiversity and structure. Besides this passive restoration approach the enrichment planting system supplements biological diversity by reintroducing certain key species to hasten the process of recovery. To accelerate the succession process, direct 
sowing is in use. Scattered tree plantings are often used in abandoned farmlands with grasslands and shrubs and at sites without any trees. To attract seed dispersing birds the so-called close- space planting system and the dense plantings of trees is recommended (Tucker and Murphy, 1997).

The so-called "Rainforestation Farming" system protects the biodiversity and provides new habitats for local species and helps to reestablish the ecological functions of a given ecosystem. At the same time it provides subsistence farmers with a stable and long-term income (Ahrens (2004), Vilei (2010), Neuberger (2010), personal communication).

The "Rainforestation Farming" system works, after research studies particularly during the 1990's (Margraf and Milan, 1991,1996, Engler, 1992, Klee, 1992, Grüninger, 1993, Balzer, 1993, Balzer and Margraf, 1994, Dargantes and Koch, 1994, Diputado, Briones, and Dargantes, 1994, Denzer, Henle, Gaulke, Margraf, and Milan, 1994, Belonias and Banoc, 1994, Quimio, 1994, Schütz, 1994, Widmann, 1994, Müller-Edzard, 1994, Asio, 1996, Ceniza, 1995, Dargantes, 1966, Waible,Wessler, and Dirksmeyer, 1997, Widmann, 1998, Fessel and Balzer, 1999, Göltenboth and Göltenboth, 2000, Schoppe, 2000, Schulte, 2002) with the hypothesis that "a farming system in the humid tropics is increasingly more sustainable the closer it is in its species composition to the original local rainforest" (Milan \& Margraf 1994).

The relatively extensive and ongoing research has also to focus on the question which species are most suitable for restoration and rehabilitation at specific localities. Native species from the immediate area are clearly most desirable and only if the site has become too degraded to permit native species to re-colonise it, exotic species may be appropriate. A number of considerations concerning the selection of species are given in Table 2.

\section{Approaches in "Rainforestation Farming" at the Site Level}

In the past, the most common approach has been to simply restore economic productivity. Other approaches attempt "complete" ecological restoration. The goal of production gains together with improvements in biodiversity and ecosystem functions leading to more sustainable forms 
Table 2. Some crucial characteristics of key plant species for restoration and rehabilitation (after Lamb \& Gilmour, 2003)

\begin{tabular}{ll} 
Species Type & Purpose \\
\hline - Native Species & - to enhance bio diversity \\
- Species attractive to frugivores & - to encourage seed dispersal \\
- Species forming mutualistic & - to foster wildlife populations \\
relationships with animals & - to facilitate their colonization \\
- Poorly dispersed species & - to increase their populations \\
- Rare or threatened species & - to occupy sites and exclude weeds \\
- Fast-growing species & - to facilitate rehabilitation \\
- Species tolerant of poor soils & - to improve soil fertility \\
- Nitrogen-fixing species & - to provide economic "goods" \\
- Economically or socially beneficial & \\
plants & - to use in fire-prone landscapes \\
- Fire tolerant plants &
\end{tabular}

of production is a more recent and realistic approach (Allen, Brown, and Allen (2001), Zedler et al. (2001)).

This approach involves the intensive planting of a relatively large number of tree species with up to 1000 trees per ha. The first year of planting focuses on sun-demanding native pioneer tree species. Initial ring weeding to avoid overgrowth of the young seedlings, particularly by winding creepers, is needed. In the second year, shade loving tree species can be planted in the shade of the pioneer species. A narrow distance planting with $2 \times 2 \mathrm{~m}$ closes the canopy fast with the effect that the bole growth is straight and the grass is shaded out rapidly (Fig. 7-8).

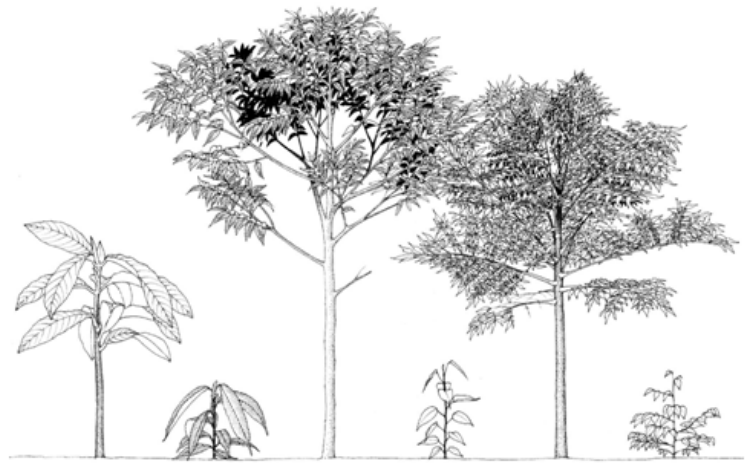

Figure 7. Examples of sun-loving Philippine pioneer trees in combination with shade demanding hard wood lumber trees (after Margraf and Milan, 1996).

From left to right: Myrica javanaica $\left(1^{\text {st }}\right.$ year $)$, Dipterocarpus validus $\left(2^{\text {nd }}\right.$ year), Trema orientalis (1 st year), Pentacme contorta ( $2^{\text {nd }}$ year), Melia dubia ( $1^{\text {st }}$ year $)$, Hopea malibato $\left(2^{\text {nd }}\right.$ year $)$ 


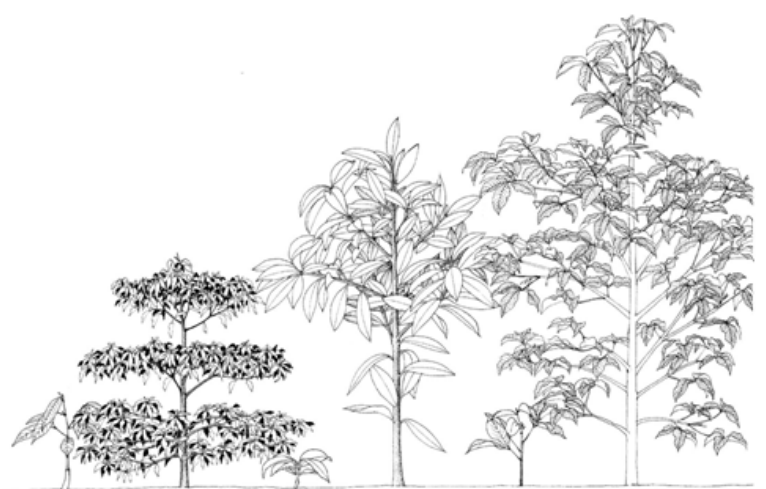

Figure 8. Indigenous rainforest trees in the Philippines in combination with shade loving fruit trees (after Margraf \& Milan 1996). From left to right: Durio zibethinus ( $2^{\text {nd }}$ years), Terminalia microcarpa ( $1^{\text {st }}$ year $)$, Garcinia mangostana ( $2^{\text {nd }}$ year), Calophyllum blancoi ( $1^{\text {st }}$ year $)$, Nephelium lappaceum ( $2^{\text {nd }}$ year $)$, Vitex parviflora $\left(1^{\text {st }}\right.$ year.)

Some tree species, like the species belonging to the family of Dipterocarpaceae do have the ability to grow straight through the overlaying canopy. Through careful thinning a three-storey structure can be achieved (Fig. 9)

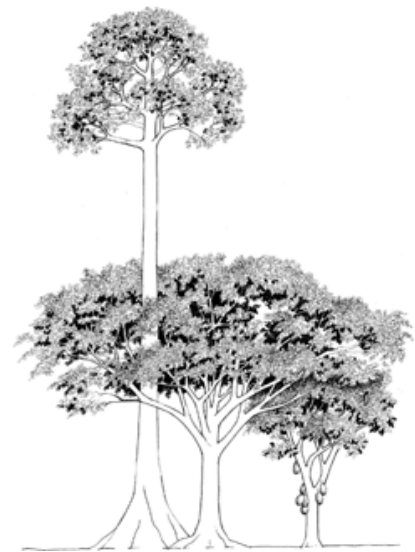

Figure 9. Near-to-nature three-storey tree farm structure as result of the

"Rainforestation Farming"approach (after Margraf \& Milan 1996).

By this "Rainforestation Farming Technology" which is a specific form of agro-ecology for the humid tropics, a close-to-nature grouping of trees in combination with other farm products is the goal. This approach 
reduces the competitiveness for resources, helps to avoid outbreaks of pests, and provides new habitats for pollinators, seed dispersers and members of the local biodiversity. It is recommended to include farm products which are shade tolerant, like aroids and zingibers, orchids and anthurium. The farming system is shifting gradually from a sundemanding cropping system to a shade-tolerant system of farming including fruits and timber. After about 4-5 years the timber from the pioneer species and first fruits can increase the income by about 8-10\%. After about 12-15 years it can be expected that the income from quality timber species will provide a sustainable high income (Fig. 10).

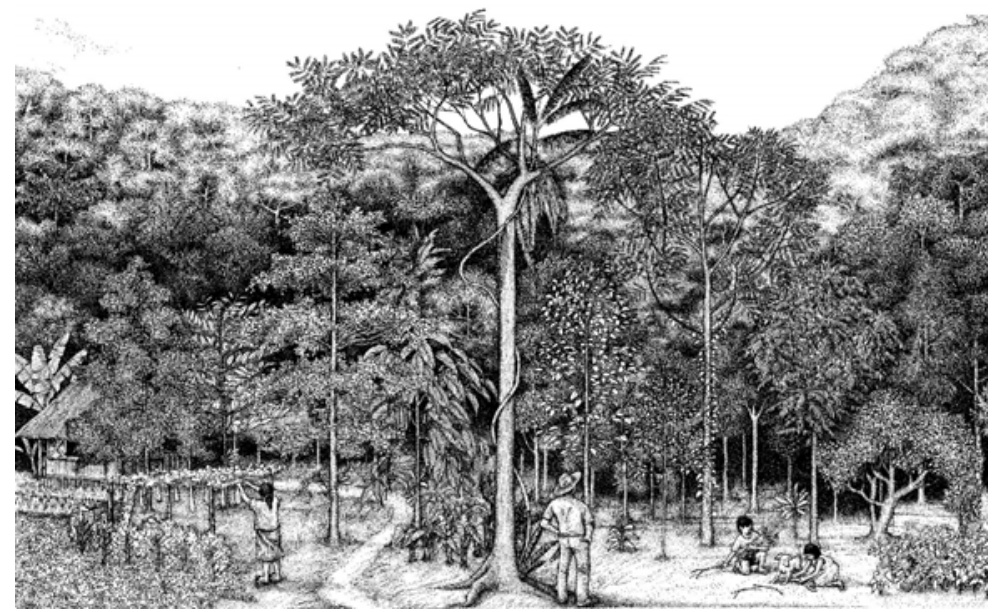

Figure 10. An idealised subsistence "rainforestation farm" after about 12-15 years (after Margraf \& Milan 1966).

After the removal of the pioneer species the former relatively dense planting scheme is changed to a wider spaced system leaving enough space to the individual development of the remaining trees and therefore reducing further the competitiveness.

The strict rule to only use indigenous trees in the scheme is of crucial importance if the biodiversity aspect, besides the income aspect, is of central importance. Biodiversity protection and support is achieved mainly in three ways (Goeltenboth and Hutter, 2004):

1. Actively through the propagation and planting of endangered tree species in a near-to-nature planting scheme. 
2. Passively through the creation of suitable habitat and microclimate to which the species migrate from adjacent secondary growth area.

3. By efforts to protect the remaining mother-trees, which provide the seeds needed for the nurseries.

Particularly the upper parts of watersheds play a prominent role in providing all the essential ecological functions keeping the middle- and lowlands as well as the coastal areas intact as major productive areas for the rural population. An exemption from the hypothesis that "a farming system in the humid tropics is increasingly more sustainable the closer it is in its species composition to the original local forest" are the irrigated rice field ecosystems. They are, by their aquatic nature, more sustainable as they function as nutrient traps, provide efficient nutrient cycling within a highly diverse aquatic biocoenosis and offer a sustainable environment for efficient nitrogen fixation (Milan and Margraf, 1994) ( Fig. 11).

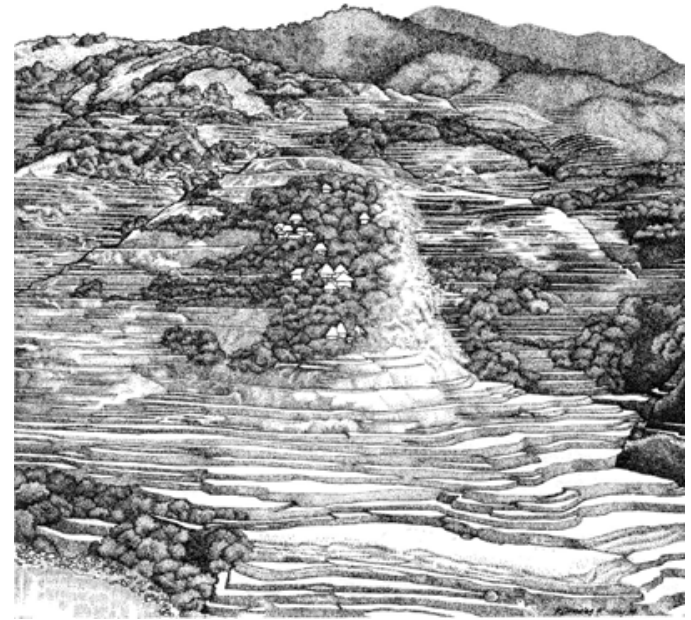

Figure 11. Irrigated rice terraces in a mountain area in South East Asia showing the hamlet as part of the ecosystem surrounded by home-gardens and fruit trees (after Voggelsberger and Margraf, 1988).

Besides environmental and socio-economic considerations, sustainability considerations were of specific interest during the gradual development of the "rainforestation farming technology" for landscape ecology restoration.

Agro-ecosystem structure and functioning are very closely related and affect the landscape sometimes in a very dramatically way. It is further 
well known that ecosystems usually do not show sharp boundaries between each other. Rather they grade gradually in time and space. The importance of local ecotones and the interrelationship between indigenous subpopulations in more or less isolated patches within a landscape have also to be considered.

Under this aspect the use of exotic "miracle trees" like Eucalyptus spp. for large scale reforestation is by no means to recommend.

The potential of a gradual transition of former monoculture stands, like worn-out coconut plantations in the Philippines, into a highly-diverse rainforestation farming system is easily recognised by land-owners and farmers, because it minimizes their economical risk and provides a sustainable income while at the same time contributes to the environmental stabilization of a given region (Fig. 12-16)

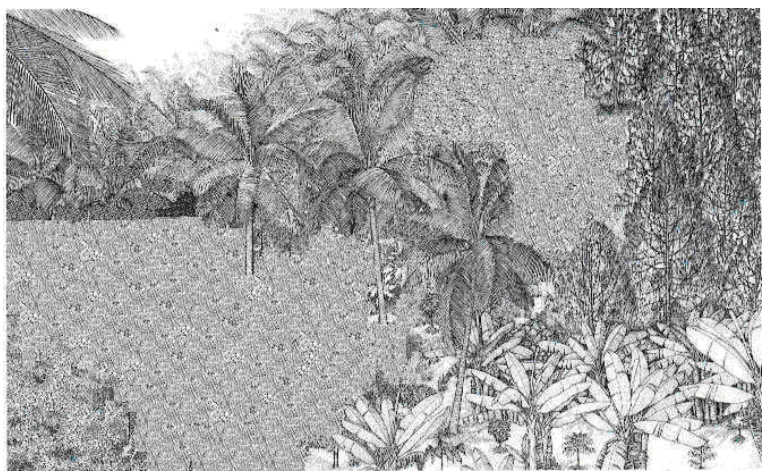

Figure 12. Worn-out coconut plantation as found in the Philippines (after Neuberger, 2005)

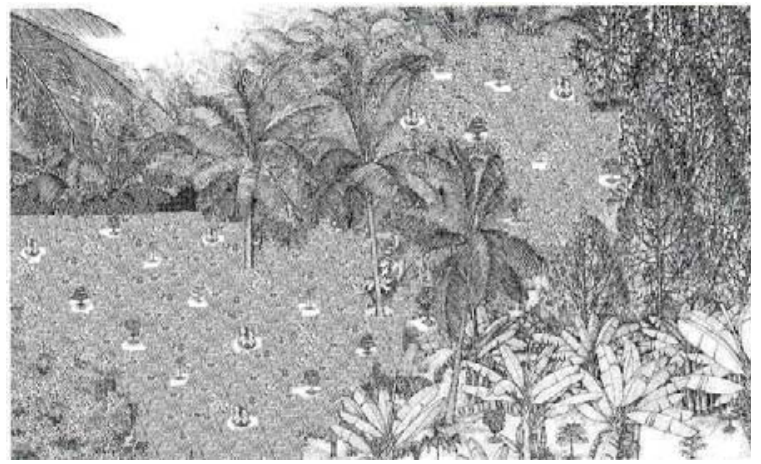

Figure 13. First year planting of sun-demanding pioneer species (after Neuberger, 2005) 


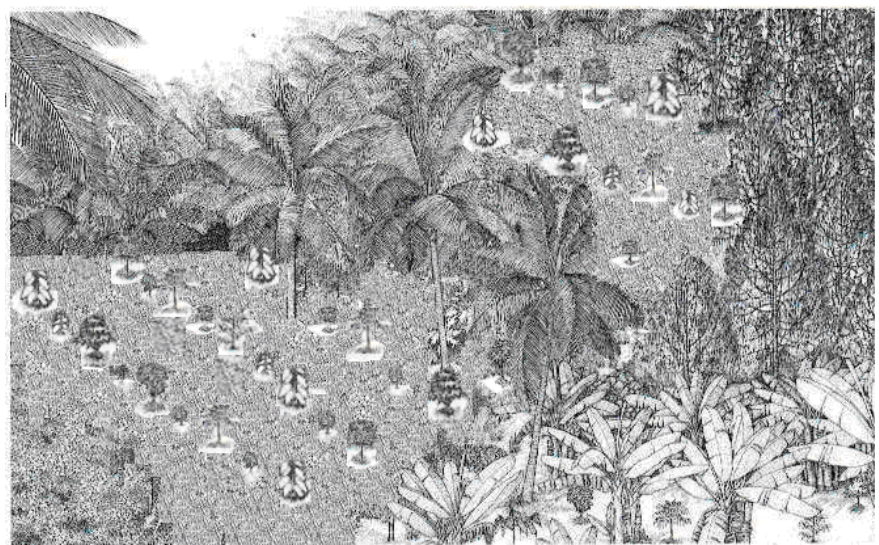

Figure 14. Second year planting of shade loving species (after Neuberger, 2005)

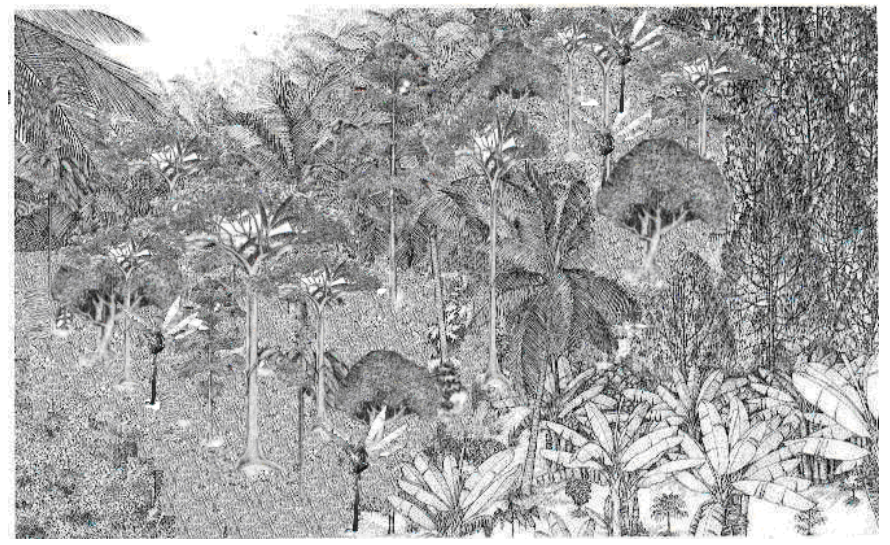

Figure 15. Emerging Rainforestation Farm in the $5^{\text {th }}$ years after establishment. (after Neuberger, 2005).

Agro-forestry systems like the "Rainforestation Farming "system are highly diverse systems. Due to the relatively quick growth of the pioneer species and the long lasting provision of photosynthetic activity by all the growing tree species these areas are significant sinks for atmospheric carbon-dioxide. If only about $5 \%$ of the growing or standing tree inventory will be harvested at any time, as recommended, and most of the biomass will remain at the site it can become a substantial input under the aspect of carbon sequestration. It is calculated that an amount of about $150 \mathrm{Mg}$ per ha of carbon-dioxide can be absorbed by a "rainforestation" farm in the Philippines. 


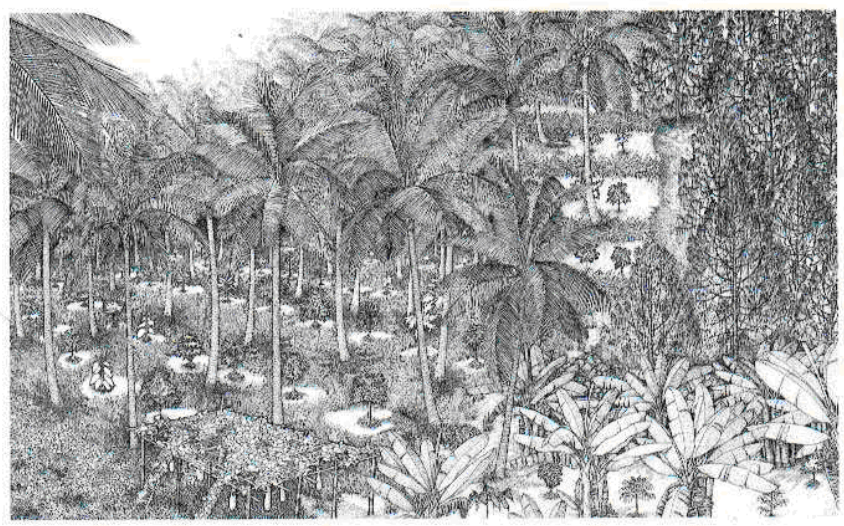

Figure 16. The established "Rainforestation Farm" under a still further existing coconut plantation (Milan and Goeltenboth, 2005)

The "Rainforestation farming technology" allows for the reforestation of degraded areas and worn-out plantations with a highly diverse and economically future-oriented, sustainable tree farm. This system is feasible for many areas in the humid tropics and can become a substantial contribution to stop the ongoing destruction of remaining primary forest areas by desperate farmers, rehabilitate degraded rural environments and landscapes and give rural people a perspective of a sustainable income to sustain their subsistence on a generation scale.

\section{REFERENCES}

ALLEN, E., J. S. BROWN, and M. ALLEN. 2001. Restoration of animal, plant and microbial diversity. In: Encyclopedia of biodiversity. Vol. 5 (S. A. Levin, ed). Academic Press, 185-202.

AHRENS, O., S. HENDERS, M. LANKAU, S. LINDEMANN, T. MÜLLER, and M. PETRI. 2004. Cost - benefit analysis. Comparison of different land uses in Leyte, Philippines. Report, Fac. Forest Sciences and Wood Ecology, Georg-August-University, Göttingen; unpublished. 
ASIO, V. B. 1996. Characteristics, weathering, formation and degradation of soils from volcanic rocks in Leyte, Philippines. Hohenheimer Bodenkundliche Hefte 33, Stuttgart, Germany.

BALZER, P. 1993. Untersuchungen zur Mikroflora von sechs Standorten auf der Insel Leyte. MSc thesis, University Hohenheim, Stuttgart, Germany.

BALZER, P. and J. MARGRAF. 1994. Recent rainfall trends in VISCA, Baybay, Leyte. Annals of Tropical Research 16(4):33-42.

BELONIAS, B. S. and L. M. BANOC. 1994. Species diversity and distribution of pteridophytes in Mt. Pangasugan. Annals of Tropical Research 16(2):30-38.

CENIZA, M. J. C. 1995. Arthropod abundance and diversity in different ecosystems of Mt. Pangasugan, Baybay, Leyte, Philippines with special reference to coleoptera and hymenoptera fauna. PLITS, Vol. 12(3), W\&S Koch Verlag, Stuttgart, Germany.

DARGANTES, B. B. 1996. Socio-ecological case studies on the occupation and cultivation in Leyte, Philippines. PLITS Vol. 14(2), W.\& S. Koch Verlag, Stuttgart, Germany.

DARGANTES, B. B. and W. KOCH. 1994. Case studies on the occupation and cultivation of the forest lands of Leyte, Philippines. Annals of Tropical Research 16(2):13-29.

DENZER, W., K. HENLE, M. GAULKE, J. MARGRAF, and P. P. MILAN. 1994. Annotated checklist of the reptiles and anphibians of Leyte, Philippines, with notes on their ecology and conservation. Annals of Tropical Research 16(4):44-70.

DIPUTADO, M. T., E. D. BRIONES, and R. D. DIALIMAS. 1994. Distribution of aranoids and epiphytes in Mt. Pangasugan ecosystems 
according to elevation. Visca-GTZ Terminal report, Visca, Baybay, Philippines, pp. 44; unpublished.

ENGLER, A. 1992. Ökologische Untersuchungen zur Arthropodengemeinschaft aus Süsskartoffeln in Abhängigkeit von der Umgebungsvegetation auf der Insel Leyte, Philippinen. MSc thesis, University Hohenheim, Stuttgart, Germany.

FESSEL, H. H. and P. BALZER. 1999. A selection of native Philippine orchids. Times Editions, Singapore.

GOELTENBOTH, F. 1999. Rainforestation Farming- an innovative approach for sustainable land use and biodiversity conservation in the Philippines. EcoSys. Suppl. Bd. 28, Kiel, 3-16.

GOELTENBOTH, F. and A. GOELTENBOTH. 2000. Agro-ecological comparison of "rainforestation" farming sites on Leyte, Philippines. Proc. Dt. Tropentag 2000,University Hohenheim, Stuttgart, Germany, 84-85.

GOELTENBOTH F. and HUTTER C.-P. 2004. New options for land rehabilitation and landscape ecology in Southeast Asia by "rainforestation farming". Journal for Nature Conservation 12, 181189.

GOEltenBOTH, F., K. H. TimotiUs, P. P. MilAN, and J. MARGRAF. 2006. Ecology of Insular Southeast Asia - The Indonesian Archipelago. Amsterdam: Elsevier, Netherlands.

GRÜNINGER M. 1993. Agrarökologische Untersuchungen zur Homopteren- und Hymenopterenfauna verschiedener ManiokAnbausysteme auf der Insel Leyte, Philippinen unter besonderer Berücksichtiogung des Mattenschildlaus Aleyrodicus dispersus Russel (Homenoptera: Aleyrodidae). MSc thesis, University Hohenheim, Stuttgart, Germany. 
KLEE, R. 1992. Untersuchungen zur Segetalflora im Süßkartoffelanbau der Insel Leyte, Philippinen. MSc thesis, University Hohenheim, Stuttgart, Germany.

LAMB, D. and D. GILMOUR. 2003. Rehabilitation and restoration of degraded forests. Gland: IUCN, Swizerland.

MARGRAF, J., and P. P. MILAN. 1991. Endangered freshwater fish communities of Leyte Rivers, Philippines. Proc. Int. Conf. Conserv. and Managm. of tropical inland waters: Problems, solutions and prospects. Hong Kong.

MARGRAF, J. and P. P. MILAN. 1996. Ecology of lowland evergreen forests and its relevance for island rehabilitation on Leyte, Philippines. In: Lowland evergreen forest ecosystems (A. Schulte and D. Schöne, eds). Singapore: World Scientific. pp. 124-154.

MILAN, P. P. and J. MARGRAF. 1994. Rainforestation Farming: An alternative to conventional concepts. Annals of Tropical Research, 16(4):17-27.

MILAN, P. P. and F. GOELTENBOTH. 2005. Abaca and Rainforestation Farming. A guide to sustainable farm management. Leyte State University, Baybay, Leyte, Philippines.

MÜLLER-EZARD, C. 1994. Untersuchungen zur Artenzusammaensetzung, Häufigkeitsverteilung und Größenklassenzusammensetzung verschiedener Gehölzarten auf 2 x 0.5 ha Primärwald am Mt. Pangasugan, Leyte, Philippines. MSc thesis, University Bayreuth, Bayreuth, Germany.

NEUBERGER, A. 2005. Rainforestation Farming. Geo-Economical and landscape relevant aspects of the Philippine approach for suibsistence and ecosystem improvement. MSc thesis, University of Tuebingen, Tuebingen, Germany; unpublished. 
NEUBERGER A. 2010. Creating new ground for sustainable livelihoods in the Philippines. Case studies on vulnerability and livelihood security on Leyte Island. PhD thesis, University Freiburg, Germany (unpublished).

PAROTTA J., AND KNOWLES O.H. 2001. Restoring tropical forests on land minded for bauxite: Examples from the Brazilian Amazon. Ecological Engineering 17, 219-239.

QUIMIO C.A. 1994. Bryophytes of river valleys and kaingin areas of Mt. Pangasugan, Leyte, Philippines. Annales of Tropical Research 16(2): 28 .

SCHOPPE S. 2000. Echinoderms of the Philippines. Times Editions, Singapore

SCHULTE A. 2002. Rainforestation Farming: Option for rural development and biodiversity conservation in the humid tropics of Southeast Asia. Shaker Verlag, Aachen, Germany.

SCHÜTZ P. 1994. Zur Bedeutung von Schwärmern (Sphingidae, Lepidoptera) bei der Bestäubung von Frucht- und Forstbäumen in Agroforestry-Systemen auf Leyte, Philippinen. MSc thesis, University Hohenheim, Stuttgart, Germany.

TUCKER N.J., AND T. M. MURPHY. 1997. The effects of ecological rehabilitation on biodiversity recruitment: Some observations from the wet tropics of north Queensland. Forest Ecology and Management 99: 133-152.

VILEI S. 2010. Participatory evaluation of sustainability of farming systems in the Philippines. PhD thesis. University Hohenheim, Stuttgart, Germany (unpublished). 
VOGGELSBERGER, M. and J. MARGRAF. 1988. Ifugao Reisterrassen: Agrarökologische Untersuchungen im Bergland der Philippinen. PLITS 1988/6 (3). Verlag Margraf, Weikersheim, Germany.

VOSTI, S. 2001. The role of agriculture in saving the rain forest. In: The Unfinished Agenda. Perspectives on overcoming hunger, poverty and environmental degradation (P. Pinstrup-Andersen and $\mathrm{R}$. Pandaya-Lorch, eds). Int. Food Policy Res. Inst., Washington D.C., USA. pp. 139-143.

WAIBEL, H., J. WESSLER, and W. DIRKSMEYER. 1997. The economics of reforestation farming. In: Proc. Int. Conf. reforestation with Philippine species for biodiv. protection and economic progress (J. F. Margraf, F. Goeltenboth, and P. P. Milan, eds). Palo, Philippines, 286-301.

WIDMANN, P. 1994. Zur Bedeutung der Flughunde (Pteropodidae) bei der Bestäubung in Agroforestry Systemen auf Leyte, Philippinen. MSc thesis, University Hohenheim, Stuttgart, Germany.

WIDMANN, P. 1998. Guide to the ecosystems of Palawan. Times Editions. Singapore.

WILSON, E. 2001. The Earth's environmental woes- is agriculture part of the problem or part of solution? In: The Unfinished Agenda. Perspectives on overcoming hunger, poverty and environmental degradation (P. Pinstrup-Andersen and R. Pandaya-Lorch, eds). Int. Food Policy Res. Inst., Washington D.C. USA. pp.103-107. 